I første kapittel handler det om generelle prinsipper for antibiotikabehandling, herunder problemene ved peroral versus intravenøs behandling, lengde av behandling og bredspektrede kontra smalspektrede antibiotika. Etter en gjennomgang av virkningsmekanismer kommer et avsnitt om farmakokinetiske prinsipper for behandling. I dette avsnittet er det flere nyttige illustrasjoner.

Forfatteren går på en enkel måte gjennom resistenstesting og resistensmekanismer. Det er et bra kapittel om multiresistente bakterier som meticillinresistente stafylokokker (MRSA), gramnegative bakterier med utvidet betalaktamaseproduksjon (ESBL), vankomycinresistente enterokokker (VRE), penicillinresistente pneumokokker (PRSP) og karbapenemresistente gramnegative staver (KPC). Dette er forkortelser som vi dessverre også må lære ettersom forekomsten av multiresistente bakterier i Norge har økt betraktelig de siste årene. Amyes avslutter med anbefalinger om hvordan man kan bruke antibiotika på en fornuftig måte for å forhindre/utsette resistensutvikling. Disse skiller seg ikke nevneverdig fra det som man anbefaler i flere norske, lokale antibiotikahåndbøker. Forfatteren kommer ikke med konkrete retningslinjer for hvordan man behandler spesifikke infeksjoner.

På en kortfattet måte får man en god forståelse av hvorfor man bør bruke antibiotika med forstand, og boken kan bidra til en bedre forståelse av antibiotikabehandling. Den støtter opp om den skandinaviske antibiotikatradisjonen.

\section{Dag Berild}

Avdeling for fordøyelsessykdommer og infeksjonsmedisin

Oslo universitetssykehus, Aker

\section{Kortfattet og godt om akuttkardiologi}

Myerson SG, Choudhury RP, Mitchell AR, red. Emergencies in cardiology

2. utg. 456 s, tab, ill. Oxford: Oxford University Press, 2009. Pris GBP 22

ISBN 978-0-19-955438-6

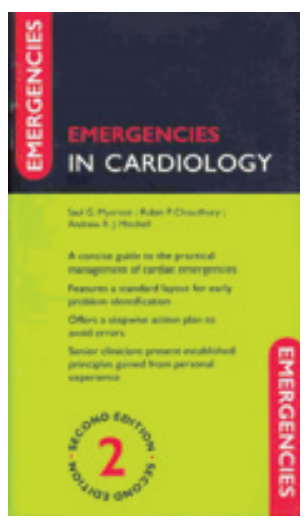

Denne utgivelsen inngår i en serie fra Oxford University Press som omhandler «Emergencies» $\mathrm{i}$ ulike medisinske fagfelt. Formatet er egnet for lommen, den er innbundet i plast og har en innholdsfortegnelse som gjør det lett å finne frem. Det er tre hovedavsnitt. Første avsnitt består av fem symptomorienterte kapitler. Stikkordsmessig beskriver man hvordan pasienter med sirkulasjonskollaps, brystsmerter, dyspné, synkope og palpitasjoner skal vurderes. Disse kapitlene har størst nytte som huskelister som kan redusere risikoen for å glemme viktige differensialdiagnoser. Det neste avsnittet utgjør hoveddelen og består av 16 kapitler hvor spesifikke tilstander som akutt koronarsyndrom, akutt hjertesvikt, arytmier og andre emner omtales. Kardiologiske problemer under svangerskap og i forbindelse med kirurgiske inngrep har egne kapitler, det samme gjelder akutte tilstander ved medfødte hjertefeil.

Forfatterne lykkes i å komme med mye relevant informasjon på relativt få sider. Bruk av stikkord, oversiktlige tabeller og en del enkle, men gode illustrasjoner gjør stoffet lett tilgjengelig, samtidig som det er utfyllende. Man omtaler symptomer, kliniske funn, diagnostiske og behandlingsmessige tiltak. Behandlingen beskriver man detaljert med angivelse av medikamentvalg og dosering. De anbefalingene som forfatterne gir, samsvarer stort sett med norske behandlingstradisjoner, men noen unntak finnes. Det er f.eks. ikke fullt samsvar mellom bokens og den gjeldende norske algoritme for hjerte-lunge-redning. På et annet sted anfører man at pasienter med gjennomgått hjerteinfarkt ikke kan kjøre bil den første måneden.

I det siste avsnittet beskriver man kortfattet en del praktiske prosedyrer som er relevante i akutt kardiologi (sentral venepunksjon, Swan-Ganz-kateter, temporær pacemaker, arteriekran, perikardtapping, aortaballongpumpe). I siste avsnitt er det også en samling av typiske EKG-eksempler fra flere tilstander. Kvaliteten på EKGeksemplene er noe varierende.

I serien av ulike oppslagsmuligheter, både i bokform og på nett, fremstår denne boken som et godt alternativ. Den vil ha størst nytte for den litt ferske primærvakten på en medisinsk avdeling hvor akutt kardiologi utgjør en stor del av de vaktmessige utfordringene. Den medisinske bakvakten som ikke har kardiologi som sitt primære felt, vil også finne den anvendelig. Deler vil også være hensiktsmessige for hjertespesialisten når det er behov for en rask repetisjon og oversikt over mindre vanlig forekommende tilstander.

\section{Rune Wiseth}

Klinikk for hjertemedisin

St. Olavs hospital

\title{
En liten tungvekter
}

Luqmani R, Pincus T, Boers M, red. Rheumatoid arthritis

$168 \mathrm{~s}$, tab, ill. Oxford: Oxford University Press, 2010. Pris GBP 6

ISBN 978-0-19-955675-5

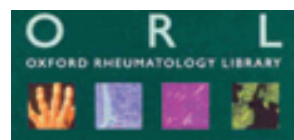

Arthritis
Rheumatoid

En liten bok kan inneholde mye nyttig informasjon. I Oxford universitetsbiblioteksserie er det tidligere utgitt en rekke pocketbøker innen forskjellige fagfelt og flere innen revmatologi. Nå har en trio verdenskjente revmatologer greid å formidle mye oppda-

tert fagstoff om revmatoid artritt på få sider.

Målgruppen er revmatologer og spesialistkandidater i revmatologi som raskt kan slå opp emner innen revmatoid artritt. Kapitlene er oversiktlig strukturert med god balanse mellom tekst, tabeller og illustrasjoner. Teksten er saklig uten overflødige ekskurser, men forfatterne formidler også tydelig hva de selv mener. De er selv sentrale i forskningen om revmatoid artritt.

Forfatterne forsøker å gi en oversikt over dagens forståelse av revmatoid artritt med hensyn til patogenese, sykdomsmekanismer, kliniske fenomener og undersøkelser. Behandlingsmuligheter får naturligvis mye plass, og oversikten over biologiske medikamenter og deres virkningsmekanismer er godt forklart.

Noen bevis for den utmerkede aktualiteten er at forfatterne fremlegger hvordan genetikk er i ferd med å gjøre sitt inntog også i revmatologien, og man gir en oversikt over kandidatgener som kan knyttes til sykdomsgenesen og risikoen for revmatoid artritt. Andre viktige områder, som evaluering av sykdomsrespons og hjerte- og karmanifestasjoner, er presentert på en oppdatert måte.

Om jeg skulle ønske meg noe, så måtte det være litt mer utfyllende drøfting av bildediagnostikkens forskjellige modaliteter og dens muligheter i diagnosen og evalueringen av behandlingsresponsen. Men alt $i$ alt dekker denne lille boken mer enn man kunne ønske seg - størrelsen tatt i betraktning.

\section{Till Uhlig}

Revmatologisk avdeling

Diakonhjemmet Sykehus Oslo 